\title{
Advances in muscle imaging for Emery-Dreifuss muscular dystrophy
}

\author{
Nicola Carboni \\ From 1st French-Italian meeting on laminopathies and other nuclear envelope-related diseases \\ Marseille, France. 15-16 January 2015
}

Laminopathies are a heterogeneous group of disorders related to alterations on genes coding for proteins of the nuclear envelope. Among these clinical entities, there are several diseases affecting mainly the cardiac and skeletal muscles. These disorders include forms with a selective cardiac compromise and muscular dystrophies (autosomal and X-linked forms of Emery-Dreifuss muscular dystrophy, Limb girdle muscular dystrophy 1B, LMNA-related congenital muscular dystrophy and other rare clinical entities). We performed imaging studies on a large cohort of subjects bearing either LMNA or EMD gene mutations; each patient enrolled displayed variable compromise on posterior legs' muscles, ranging from mild compromise on soleus and medial head of gastrocnemius to overt alterations on soleus, medial head of gastrocnemius $[1,3]$. Of note, we saw that even subjects presenting with clinically selective cardiac compromise displayed, on imaging studies, variable alterations on skeletal muscles. This findings showed a continuum in skeletal muscles compromise among different phenotypes related to $L M N A$ or $E M D$ gene mutations and lead to hypothesize a common mechanism in the process of damage of skeletal muscles fibers.

Published: 11 November 2015

\section{References}

1. Carboni N, Mura M, Mercuri E, Marrosu G, Manzi RC, Cocco E, et al: Cardiac and muscle imaging findings in a family with $\mathrm{X}$-linked Emery-Dreifuss muscular dystrophy. Neuromuscul Disord 2012, 22(2):152-8.

2. Carboni N, Mura M, Marrosu G, Cocco E, Marini S, Solla E, et al: Muscle imaging analogies in a cohort of patients with different clinical phenotypes caused by LMNA gene mutations. Muscle Nerve 2010, 41(4):458-63.

3. Carboni N, Mura M, Marrosu G, Cocco E, Ahmad M, Solla E, et al: Muscle MRI findings in patients with an apparently exclusive cardiac phenotype

Correspondence: nikola.carboni@tiscali.it

Division of Neurology, San Francesco Hospital of Nuoro, Nuoro, Italy due to a novel LMNA gene mutation. Neuromuscul Disord 2008, 18(4):291-8.

doi:10.1186/1750-1172-10-S2-026

Cite this article as: Carboni: Advances in muscle imaging for EmeryDreifuss muscular dystrophy. Orphanet Journal of Rare Diseases 2015 10(Suppl 2):O26.
Submit your next manuscript to BioMed Central and take full advantage of:

- Convenient online submission

- Thorough peer review

- No space constraints or color figure charges

- Immediate publication on acceptance

- Inclusion in PubMed, CAS, Scopus and Google Scholar

- Research which is freely available for redistribution
() Biomed Central
() Biomed Central

C 2015 Carboni This is an Open Access article distributed under the terms of the Creative Commons Attribution License (http://

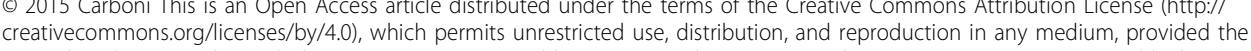
original work is properly cited. The Creative Commons Public Domain Dedication waiver (http://creativecommons.org/publicdomain/ zero/1.0/) applies to the data made available in this article, unless otherwise stated. 